\title{
JAWNOŚĆ ROZPRAWY GEÓWNEJ W PROCESIE KARNYM W ŚWIETLE NOWELIZACJI KODEKSU POSTĘPOWANIA KARNEGO Z 2016 ROKU
}

Rozprawa główna jest tym etapem postępowania sądowego i procesu karnego w ogóle, w ramach którego walory zasady jawności uwidaczniają się bardzo wyraziście i szczególnie. Jawność obowiązuje w postępowaniu karnym z uwagi na rangę wartości, interesów i dóbr podlegających w tym przypadku ochronie, a także z powodu społecznego odzwierciedlenia faktu popełnienia przestępstwa oraz w aspekcie dążenia do realizacji interesu państwa w przywróceniu porządku naruszonego tym czynem¹․ Zasada jawności procesowej jest w swej istotności bez wątpienia równoważna tym wszystkim zasadom, na których musi opierać się wymiar sprawiedliwości, który w porządku demokratycznym odnajduje podstawę w suwerenności narodu ${ }^{2}$. Jako instrument demokracji w odniesieniu do rozprawy głównej jawność oznacza zagwarantowanie ogółowi szczególnej formy wolności polegającej na obecności na rozprawie, obserwowaniu i kontrolowaniu jej przebiegu oraz decyzji sądowych, a tym samym tworzy podwaliny zróżnicowania w postaci sądu reprezentującego wszystkich, w tym oczywiście także państwo, oraz społeczeństwa uczestniczącego w rozprawie za pośrednictwem publiczności i przedstawicieli środków przekazu $^{3}$. W tej sytuacji oczywisty jest fakt, że jawność zapewnia szerszą widoczność działań władzy publicznej i ich efektów.

Jednakowoż trudno byłoby zanegować tezę wykluczajaccą nadanie jawności rozprawy charakteru bezwzględnego, niepodlegającego żadnym ograniczeniom czy wyjątkom. Żadna zresztą zasada procesowa nie obowiązuje w postępowaniu karnym w sposób nieograniczony. Sporna może się okazać wyłącznie kwestia granic obowiązywania zasady jawności w ramach rozprawy głównej, przy czym należałoby dalej doprecyzować tę myśl w sposób następujący: uprawnione jest prowadzenie polemiki wokół kwestii owych granic, ale tylko w taki sposób, który nie podważa istoty jawności lub nie prowadzi do znaczącego, zbyt szerokiego ograniczenia zakresu respektowania tej zasady. Konstytucyjne zakotwiczenie wymogu jawnego rozpoznawania sprawy przez

\footnotetext{
1 Tak trafnie włoski TK w wyroku z 27 lipca 1992 r. Na ten temat szeroko np. P. Corso (red.), Commento al codice di procedura penale, Piacenza 2008, s. 2225.

${ }^{2}$ D. Manzione, w: M. Chiavario (red.), Commento al nuovo codice di procedura penale, t. 5 , Torino 1991, s. 59-60.

${ }^{3}$ Por. M. Chiavario, Diritto processuale penale. Profilo istituzionale, Torino 2007, s. 397; M. Bonetti, Riservatezza e processo penale, Milano 2003, s. 174; C. Ridolfi, Persona e mass media, Padova 1990, s. 117; G. Leone, Manuale di diritto processuale penale, Napoli 1975, s. 490.
} 
$\operatorname{sac}^{4}$ (art. 45 ust. 1 i 2 Konstytucji) dostarcza tutaj podstawowego, ale nie jedynego, rzecz jasna, w tej mierze argumentu.

Niniejszy artykuł ma na celu poddanie analizie tematyki tytułowej w kontekście zmian nowelizacyjnych do k.p.k. z 2016 r. Ustawa z 10 czerwca 2016 r. ${ }^{5}$ wprowadziła bowiem określone modyfikacje, które w zasadzie prowadza do zmian w zakresie modelu ukształtowania jawności rozprawy głównej. Tym samym potwierdza się założenie o nieustannym pozostawaniu zasady jawności w kręgu oddziaływania rozmaitych zjawisk i trendów występujących w ramach przestrzeni społecznej ${ }^{6}$. Naznaczenie procesu karnego dynamiką zmian nie omija więc zasady jawności, choć mogłoby się apriorycznie wydawać, że $\mathrm{w}$ tej akurat materii podatność na różnorodne przeobrażenia socjokulturowe jest relatywnie mniejsza. Tylko zatem pozornie regulacja prawna dotycząca jawności rozprawy głównej mogłaby być uznana za sztywna i zastana, niepodlegająca żadnym zmianom. Z góry trzeba zastrzec, że ramy niniejszego artykułu nie pozwalają na omówienie wszystkich zmian przewidzianych we wspomnianej ustawie nowelizacyjnej. Uwaga zostanie skoncentrowana na dwóch zmianach, które bez wątpienia można zaliczyć do węzłowych (najistotniejszych).

Pierwszy kierunek tych zmian obejmuje wyłączenie jawności rozprawy głównej. Od razu należy podkreślić, że nie uległ modyfikacji katalog przyczyn wyłączenia jawności: żadna nowa przesłanka nie została tutaj zadekretowana, jak i żadna z dotychczas obowiązujących podstaw owego wyłączenia nie została z k.p.k. usunięta. Zmienił się natomiast tryb podejmowania przez sąd decyzji w przedmiocie wyłączenia jawności rozprawy. W myśl art. 360 § 1 k.p.k. sąd wydaje fakultatywnie stosowną decyzję, a zatem wyłączenie jawności rozprawy nie ma już charakteru obligatoryjnego. Nie zmienia to faktu, że skoro jawność rozprawy ma największe znaczenie przed sądem I instancji ${ }^{7}$, tylko wyjątkowe okoliczności mogą uzasadniać wyłączenie jawności na tym etapie postępowania.

Zważyć wszak należy, że przyczyny wymienione de lege lata w art. 360 $\S 1$ pkt 1 k.p.k. (jawność mogłaby: - wywołać zakłócenie spokoju publicznego, - obrażać dobre obyczaje, - ujawnić okoliczności, które ze względu na ważny interes państwa powinny być zachowane w tajemnicy, - naruszyć ważny in-

\footnotetext{
${ }^{4}$ Szerzej w tej kwestii np. P. Wiliński, Proces karny w świetle Konstytucji, Warszawa 2011, s. 139-141; J. Skorupka, Prawnomiędzynarodowe i konstytucyjne podstawy jawności procesu karnego, w: idem (red.), Jawność procesu karnego, Warszawa 2012, s. 88-95; R. Koper, Jawność rozprawy głównej a ochrona prawa do prywatności w procesie karnym, Warszawa 2010, s. 33-39.

${ }^{5}$ Ustawa o zmianie ustawy - Kodeks postępowania karnego, ustawy o zawodach lekarza i lekarza dentysty oraz ustawy o prawach pacjenta i Rzeczniku Praw Pacjenta, Dz. U. 2016, poz. 1070.

${ }^{6}$ R. Koper, Jawność zewnętrzna postępowania sqdowego, w: W. Jasiński, K. Nowicki (red.), Jawność jako wymóg rzetelnego procesu karnego. Zagadnienia prawa polskiego i obcego, Warszawa 2013, s. 105.

${ }^{7}$ Wyrok ETPC z 23 kwietnia 1997 r., 1496/89, Stallinger i Kuso przeciwko Austrii. Na ten judykat powołuje się C. Nowak, w: P. Wiliński (red.), Rzetelny proces karny w orzecznictwie sqdów polskich i międzynarodowych, Warszawa 2009, s. 111.
} 
teres prywatny) są tego rodzaju, że mają one w istocie charakter ocenny. Na gruncie poprzedniego stanu prawnego przyjmowano analogicznie, zauważając nadto, że w praktyce może zacierać się różnica między obligatoryjnym a fakultatywnym podejmowaniem decyzji przez sąd, co z kolei może oznaczać pojawienie się ryzyka przeprowadzenia przez sąd oceny dyskrecjonalnej ${ }^{8}$. Można zatem powiedzieć, że przyznanie decyzji sądowej przymiotu fakultatywności nie powoduje w rozważanej sytuacji istotnej zmiany jakościowej. W dalszym ciagu sąd musi wnikliwie rozważyć, czy sprawa powinna być rozpoznawana przy drzwiach zamkniętych. Nadal więc zastosowanie wskazanego przepisu musi następować ostrożnie, nie mówiąc o tym, że charakter okoliczności wyszczególnionych w art. 360 § 1 pkt 1 k.p.k. sprawia, że wyłączenie jawności powinno być tutaj reguła, a tylko szczególne racje mogą spowodować, że do tego nie dojdzie ${ }^{9}$.

Fakultatywny charakter postanowienia sądu w przedmiocie wyłączenia jawności dotyczy lege non distinguente sytuacji, w której chociażby jeden z oskarżonych jest nieletni lub zachodzi potrzeba przesłuchania świadka, który nie ukończył 15 lat (art. $360 \S 1$ pkt 2 k.p.k.). Biorąc pod uwagę, że ratio regulacji zezwalającej w tych wypadkach na wyłączenie jawności tkwi w konieczności szczególnej ochrony wymienionych podmiotów (aby uniknąć wyrządzania im szkody psychicznej w związku z obecnością publiczności) ${ }^{10}$, sąd musi dokonać obiektywnego oszacowania interesu tych osób i podjać decyzję o wyłączeniu jawności, gdy tylko ustali, że ów interes wymaga rozpoznawania sprawy przy drzwiach zamkniętych.

Sąd może, ale nie musi wyłączyć jawność rozprawy także wtedy, gdy z odpowiednim żądaniem wystapiła osoba, która złożyła wniosek o ściganie (art. $360 \S 1$ pkt 3 k.p.k.). I ta zmiana nie nasuwa wątpliwości, a nawet zasługuje na wyraźna akceptację. Przed wejściem w życie przepisów ustawy nowelizacyjnej z 10 czerwca 2016 r. wspomnianym żądaniem pokrzywdzonego (lub innego podmiotu uprawnionego w zakresie złożenia wniosku o ściganie) sąd był związany, a zatem musiał w takiej sytuacji wyłączyć jawność rozprawy. Tymczasem z powodzeniem można było (i można nadal) wskazać gros przestępstw wnioskowych, które nie łączą się z ingerencją w prywatność lub inne dobra osobiste pokrzywdzonego, natomiast godzą w jego sfere majątkowo-ekonomiczna (np. przestępstwa przeciwko mieniu, przeciwko obrotowi gospodarczemu). Tym samym utrzymywany był stan przesadnego poszerzenia zakresu

${ }^{8}$ Argumentowano, że użycie sformułowania „sąd wyłącza” w połączeniu z dopuszczeniem kryterium ocennego sprawia, że ta obligatoryjność staje się względna, na ten temat np. A. Kaftal, Jawność postepowania karnego w świetle nowego kodeksu postępowania karnego, „Nowe Prawo” 1969, nr 11-12, s. 1643; P. Hofmański, S. Zabłocki, Elementy metodyki sędziego w sprawach karnych, Kraków 2006, s. 117; R. Koper, Jawność rozprawy..., s. 299 i 301; M. Brzezińska, D. Tarnowska, Wyłaczenie jawności zewnętrznej rozprawy głównej, w: W. Jasiński, K. Nowicki (red.), op.cit., s. 214 .

9 Tak również W. Jasiński, w: J. Skorupka (red.), Kodeks postępowania karnego. Komentarz, Warszawa 2016, s. 885.

${ }^{10}$ Analogicznie w literaturze włoskiej np. D. Manzione, w: M. Chiavario (red.), op. cit., s. 70; L. Scomparin, La tutela del testimone nel processo penale, Padova 2000, s. 340. 
wyłączenia jawności rozprawy, gdyż w przypadku takich czynów nie było raczej konieczności uchylania jawności zawsze, gdy pokrzywdzony wystapił ze stosownym żądaniem, a to żądanie sąd musiał na dodatek uwzględnić ${ }^{11}$.

Istotna innowacja jest zauważalna w treści art. 360 § 2 k.p.k. Zgodnie z tym przepisem, jeśli prokurator sprzeciwi się wyłączeniu jawności, rozprawa odbywa się jawnie. Ów sprzeciw przysługuje wyłącznie prokuratorowi. Nie może go natomiast zgłosić inny podmiot występujący w roli oskarżyciela publicznego.

Ten sprzeciw nie funkcjonuje tutaj w charakterze środka zaskarżenia, natomiast należy go odczytywać w sensie braku zgody prokuratora. Pełni zatem analogiczną rolę do chociażby sprzeciwu oskarżonego na warunkowe umorzenie postępowania karnego na posiedzeniu w ramach wstępnego badania sprawy (art. $341 \S 2$ k.p.k.). Tak jak bowiem wskazany sprzeciw oskarżonego całkowicie wyłącza możliwość zastosowania wobec niego instytucji z art. 66-68 k.k., tak omawiany sprzeciw prokuratora całkowicie blokuje niejawne prowadzenie rozprawy przez sąd. Stylizacja art. $360 § 2$ k.p.k. nie pozostawia żadnego pola do odmiennych interpretacji. Rozważany sprzeciw prokuratora nie posiada zatem - tak jak sprzeciw będący środkiem zaskarżenia (sprzeciw od wyroku nakazowego) - cechy kasacyjności, ponieważ zgoda prokuratora stanowi swoisty warunek odstapienia od jawności rozprawy. Oznacza to, że ten warunek musi być spełniony, zanim dojdzie do wyłączenia jawności, natomiast nie służy do „kasowania” podjętych już decyzji sądowych o wyłączeniu jawności.

Wykładnia językowa i logiczna art. 360 § 2 k.p.k. dostarcza zresztą silnego argumentu na rzecz przyjęcia takiej tezy ${ }^{12}$. Sformułowanie językowe „jeśli prokurator sprzeciwi się wyłączeniu jawności" należy odczytywać tylko przez konstatację, że prokurator ewentualnie może wyrazić sprzeciw jedynie przed podjęciem decyzji przez sąd, gdyż ustawodawca użył tutaj czasu przyszłego. W konsekwencji należy przyjąć, że sprzeciw prokuratora wyartykułowany po wydaniu przez sąd postanowienia o wyłączeniu jawności nie wywołuje już skutku hamującego niejawne rozpatrywanie sprawy. To wszystko oznacza, że przed podjęciem decyzji w tej kwestii sąd powinien zwrócić się do prokuratora obecnego na rozprawie o zajęcie stanowiska w przedmiocie wyłączenia jawności rozprawy ${ }^{13}$.

Prima facie mogłoby się wydawać, że identyczny obowiązek konsultacji ciąży na sądzie także wtedy, gdy prokurator występuje w roli oskarżyciela publicznego w danej sprawie, ale nie jest obecny na rozprawie. Za przyjęciem takiego rozwiązania przemawiałby fakt, że art. $360 § 2$ k.p.k. nie wprowadza wprost żadnego zróżnicowania w tym zakresie, a poza tym trzeba by wziąć

${ }^{11}$ R. Koper, Jawność rozprawy..., s. 296. Podobnie przyjmował np. R.A. Stefański, w: J. Bratoszewski, L. Gardocki, Z. Gostyński (red.), S.M. Przyjemski, R.A. Stefański, S. Zabłocki, Kodeks postępowania karnego. Komentarz, t. 2, wyd. 1, Warszawa 1998, s. 234; a także W. Jasiński, Jawność zewnętrzna procesu karnego - uwagi na tle propozycji Komisji Kodyfikacyjnej Prawa Karnego, w: W. Jasiński, K. Nowicki (red.), Jawność jako wymóg rzetelnego procesu karnego. Zagadnienia prawa polskiego i obcego, Warszawa 2013, s. 128. Przeciwne stanowisko reprezentował np. K. Nowicki, Jawność zewnętrzna postępowania sqdowego, w: J. Skorupka (red.), Jawność..., s. 339 .

${ }^{12}$ Podobnie W. Jasiński, w: J. Skorupka (red.), Kodeks..., s. 887-888.

${ }^{13}$ Ibidem, s. 888. 
pod uwagę, że - w świetle treści powołanego przepisu - zgoda prokuratora de facto w ogóle warunkuje wyłączenie jawności rozprawy. Sąd musiałby wtedy zawiadomić prokuratora, że rozważa możliwość wyłączenia jawności rozprawy i z tego powodu wzywa go do przedstawienia stanowiska. Omawiane rozwiązanie wydłużałoby ewidentnie czas trwania postępowania sądowego. W razie zgłoszenia na pierwszym terminie rozprawy przez stronę wniosku o wyłączenie jawności rozprawy w całości, musiałoby nastapić zarządzenie przerwy lub odroczenie rozprawy, gdyż trudno wówczas sobie wyobrazić przejście do etapu przewodu sądowego. Skoro więc ustawodawca używa określenia „jeśli prokurator sprzeciwi się wyłączeniu jawności”, to zapewne ma na myśli sytuacje, w których sprzeciw prokuratora następuje w bezpośredniej konsekwencji sygnalizacji przez sąd na rozprawie, że rozważa możliwość niejawnego procedowania. Innymi słowy, prokurator musi być obecny na rozprawie ${ }^{14}$, aby mógł skorzystać z uprawnienia do zgłoszenia sprzeciwu. To rozwiązanie jest w pełni funkcjonalne i wydaje się, że odpowiada intencji ustawodawcy. Rozważając - z urzędu lub na wniosek - podjęcie decyzji o wyłączeniu jawności jeszcze przed rozprawa, sąd może uznać obecność prokuratora za obowiązkową i tym samym umożliwić mu ewentualne wyrażenie sprzeciwu w tej kwestii na rozprawie przed rozpoczęciem przewodu sądowego.

Należy zauważyć, że prokurator nie ma obowiązku stawiennictwa na rozprawie w tych sprawach, w których postępowanie przygotowawcze zakończyło się w formie dochodzenia (art. $46 \S 2$ k.p.k.). Ta okoliczność mogłaby sugerować, że z uwagi na fakt, że wiele takich spraw może zakończyć się w trybie konsensualnym na posiedzeniu (art. 343 i art 343a k.p.k.), sprzeciw prokuratora ulega dezaktualizacji. Do tzw. posiedzeń wyrokowych objętych reżimem jawności zewnętrznej stosuje się jednak odpowiednio przepisy rozdziału 42 k.p.k. dotyczące jawności rozprawy (art. 95b § 3 k.p.k.), a to oznacza, że istnieje potencjalna możliwość wyrażenia omawianego sprzeciwu, gdy sąd rozważa wyłączenie jawności takiego posiedzenia. Obowiązkowy udział prokuratora $\mathrm{w}$ tego typu posiedzeniach nie jest wszak regułą (art. $343 \S 5$, art. 343a $\S 2 \mathrm{w}$ zw. z art. $343 \S 5$ k.p.k.). Jeśli zatem prokurator nie bierze udziału w tym posiedzeniu, odpada możliwość zgłoszenia omawianego sprzeciwu.

Niejasna jest kwestia zakresu dopuszczalności działania prokuratora w sytuacji opisanej w art. $360 \S 2$ k.p.k. Z pewnością sprzeciw prokuratora nie odnosi się do kodeksowych wypadków niejawnego procedowania ex lege, gdyż sąd nie podejmuje wtedy żadnej decyzji w przedmiocie wyłączenia jawności rozprawy, gdyż sam ustawodawca odgórnie przesądził, że rozprawa dla pewnej kategorii spraw nie może toczyć się jawnie (art. 359, art. 393 § 4 k.p.k.). Problematyczne jest jednak, czy sprzeciw prokuratora dotyczy tylko przyczyn wyłączenia jawności rozprawy unormowanych w art. $360 \S 1$ k.p.k. czy również tych innych, przewidzianych $\mathrm{w}$ innych przepisach k.p.k. Nie ma wattpliwości, że omawiany sprzeciw może się zaktualizować we wszystkich sytuacjach wymienionych $\mathrm{w}$ art. $360 \S 1$ k.p.k. Wydaje się, że może mieć zastosowanie - przynajmniej in abstracto - także w innych jeszcze sytuacjach. Wykładnia systemowa może

\footnotetext{
${ }^{14}$ Analogicznie: ibidem.
} 
bowiem wskazywać, że ustawodawca uregulował tę kompetencję prokuratora w rozdziale 42 k.p.k., normującym w ogóle wyłączenie jawności rozprawy, w tym podstawowe przyczyny w tej materii, a zatem chciał objąć zakresem tej kompetencji wszystkie inne kodeksowe przypadki wyłączenia jawności rozprawy, zwłaszcza że zostały one uregulowane w przepisach poprzedzających rozdział 42 k.p.k. W tym sensie sprzeciw prokuratora dotyczy nie tylko tych sytuacji, które bezpośrednio „graniczą" z unormowaniem art. 360 § 2 k.p.k. (art. 360 § 1 k.p.k.), lecz także tych innych, które zostały przewidziane we „wcześniej zlokalizowanych” przepisach k.p.k. Wszak do tych innych sytuacji odnoszą się także pozostałe przepisy rozdziału 42 k.p.k., dotyczące chociażby trybu wyłączania jawności rozprawy i skutków takiej decyzji. Należałoby więc raczej przyjacc, że prokurator może in concreto sprzeciwić się wyłączeniu jawności rozprawy przez sąd na wniosek świadka, który obawia się narażenia go na hańbę lub osoby dlań najbliższej (art. $183 \S 2$ k.p.k.). Sąd nie jest formalnie związany takim żądaniem świadka, a zatem występuje tutaj fakultatywność decyzji sądowej analogiczna do tej z art. $360 § 1$ k.p.k. W zasadzie potencjalną możliwość rozważanego sprzeciwu trzeba chyba odnosić także do sytuacji wynikającej z art. $181 \S 1$ k.p.k., gdy dochodzi do przesłuchania świadka zwolnionego z zachowania tajemnicy objętej klauzula informacji niejawnych lub tajemnicy zawodowej. Z drugiej strony trudno byłoby zrozumieć przyznanie prokuratorowi takiej kompetencji. Stwierdzenie faktu przynależności danej informacji do zakresu tajemnicy określonego rodzaju opiera się na ogół na kryteriach obiektywnych, a wyłączenie jawności rozprawy przez sąd jest wówczas w sumie obligatoryjne (,sąd przesłuchuje taką osobę [...] z wyłączeniem jawności” ${ }^{15}$. Można tutaj dostrzec pewną bezradność interpretacyjna, ale być może wykładnia logiczna i celowościowa powinny stanowić wystarczająca podstawę do zanegowania możliwości wyrażenia sprzeciwu przez prokuratora.

Wobec braku normatywnego sprecyzowania formy wyrażenia tego sprzeciwu, dla porządku wypada jeszcze dodać, że sprzeciw może przybrać formę zarówno ustna, jak i pisemną ${ }^{16}$.

To, co dotychczas zostało powiedziane w przedmiocie regulacji z art. 360 $\S 2$ k.p.k., opierało się na analizie stanu prawnego de lege lata, przy wykorzystaniu dostępnych metod wykładni. Czym innym jest natomiast ocena tego unormowania, a ta nie może być jednoznaczna.

Z jednej strony należy zgodzić się ze stwierdzeniem, że prokurator występuje w procesie karnym jako szczególny rzecznik praworządności (rzecznik

${ }_{15}$ Nie chodzi tutaj o przypadek niejawnej rozprawy ex lege, gdyż ustawodawca odwołuje się do wyłączenia jawności rozprawy, co nie zmienia faktu, że w normie zawartej w art. $181 \S 1$ k.p.k. powinna się znaleźć wyraźna wzmianka wskazująca na niejawną z mocy prawa rozprawę. Odmiennie w tej kwestii, przez zaakcentowanie de lege lata ustanowienia w tym przepisie niejawnej rozprawy ex lege, np. W. Jasiński, Bezstronność sqdu i jej gwarancje w polskim procesie karnym, Warszawa 2009, s. 396.

${ }_{16}$ M. Błaszyk, H. Paluszkiewicz, Jawność rozprawy głównej po nowelizacji kodeksu postepowania karnego, w: T. Grzegorczyk, R. Olszewski (red.), Verba volant. Scripta manent. Proces karny, prawo karne skarbowe i prawo wykroczeń po zmianach z lat 2015-2016. Ksiega pamiatkowa poświęcona Profesor Monice Zbrojewskiej, Warszawa 2017, s. 300. 
interesu społecznego ${ }^{17}$. W tym aspekcie można więc zadać pytanie: dlaczego nie przyznać prokuratorowi uprawnienia związanego z możliwością wpływu na zakres respektowania jawności rozprawy głównej? W takiej sytuacji prokurator staje się podmiotem gwarantującym transparentność postępowania sądowego w imię dobra publicznego, czyli w interesie ogółu.

Z drugiej strony pojawiają się zastrzeżenia. Prokurator jest rzecznikiem praworządności, ale - co oczywiste - na etapie postępowania sądowego jest też strona. Uzyskując uprawnienie związane z możliwością zgłoszenia sprzeciwu, prokurator staje się stroną mocno uprzywilejowaną w procesie, gdyż analogicznego uprawnienia nie posiada strona przeciwna (oskarżony). Nie chodzi tutaj o podkreślenie zasadności wyposażenia oskarżonego w identyczne uprawnienie, ale o ukazanie kontekstu sytuacyjnego łączącego się z naruszeniem reguły równości broni. Abstrahując od faktycznej nierówności obu stron (prokuratorai oskarżonego) w toku postępowania przed sądem, w sensie formalnoprawnym obie strony powinny zostać wyposażone w te same środki prawne, aby mogły skutecznie prowadzić walkęo najkorzystniejsze rozstrzygnięcie. W przypadku oskarżonego związek zasady jawności z realizacja celów postępowania karnego jest oczywisty, albowiem oskarżony, w zależności od sytuacji, może właściwie urzeczywistnić prawo do obrony albo w warunkach jawnej rozprawy, albo w wyniku wyłączenia jawności ${ }^{18}$. Rzecz tyczy się swobody w zakresie prowadzenia sporu i zapewnienia odpowiednich warunków do nieskrępowanej obrony. W tej sytuacji prokurator ostatecznie rozstrzyga o interesach procesowych drugiej strony postępowania. Tymczasem jedna strona stosunku prawnego nie może rozstrzygać o sytuacji prawnej jego drugiej strony, i to w warunkach naznaczonych ryzykiem arbitralności. W przeciwieństwie do sądu, który ma obowiązek uzasadnić postanowienie o wyłączeniu jawności rozprawy, na prokuratorze nie ciąży obowiązek umotywowania sprzeciwu ${ }^{19}$, gdyż ustawodawca zwolnił go z podania powodów, dla których nie wyraża zgody na wyłączenie jawności. Tymczasem ingerencja władzy publicznej w prawa i wolności jednostki powinna być poddana ścisłej kontroli, aby zagwarantować eo ipso ochronę adekwatna i skuteczną ${ }^{20}$. De facto prokurator rozstrzyga także o sytuacji procesowej pokrzywdzonego, gdyż może się zdarzyć sytuacja, w której pokrzywdzony (działajacy nawet jako oskarżyciel posiłkowy) wnosi o wyłączenie jawności rozprawy, a prokurator sprzeciwia się temu. Także dla pokrzywdzonego jawność rozprawy lub jej brak może mieć niebagatelne znaczenie w aspekcie stworzenia odpowiednich warunków do prowadzenia sporu. Wreszcie, prokurator, wyrażając sprzeciw wobec wyłączenia jawno-

17 Tak, w ślad za uzasadnieniem projektu ustawy nowelizacyjnej A. Ważny, w: A. Sakowicz (red.), Kodeks postepowania karnego. Komentarz, Warszawa 2016, s. 847; M. Zimna, Wyłaczenie jawności rozprawy jako gwarancja ochrony interesów uczestników postepowania karnego, „Prokuratura i Prawo" 2016, nr 9, s. 99.

18 Szerzej na ten temat np. R. Koper, Jawność rozprawy..., s. 226-229.

19 M. Błaszyk, H. Paluszkiewicz, op. cit., s. 301; W. Jasiński, w: J. Skorupka (red.), Kodeks..., s. 888 .

20 A. Gaito, Procedura penale e garanzie europee, Torino 2006, s. 123. 
ści z uwagi na ochronę interesu świadka, staje się decydentem w zakresie ochrony uczestników postępowania niebędących stronami. Także zatem w odniesieniu do pokrzywdzonego i świadka ta sytuacja oznacza pewne naruszenie równowagi procesowej.

Trzeba jeszcze dodać, że za wyłączeniem jawności mogą przemawiać względy związane z potrzebą ochrony dóbr osobistych (prywatność, cześć) uczestników procesu. Wprawdzie ochrona tych dóbr uzyskuje tutaj charakter pozaprocesowy, niemniej powinna być w procesie respektowana. Zwłaszcza tam, gdzie w grę wchodzi ochrona intymności jako tej najściślejszej i najbardziej osobistej sfery prywatności, sprzeciw prokuratora może narazić oskarżonego, pokrzywdzonego czy świadka na upublicznienie pewnych okoliczności w ramach stanu nieodwracalnego. Skoro bowiem w świetle prawa prokurator jest władny sprzeciwić się wyłączeniu jawności rozprawy z uwagi na ważny interes prywatny uczestnika procesu czy ze względu na obawę narażenia świadka na hańbę, to zainteresowanemu nie przysługuje potem możliwość skutecznego domagania się ochrony przed sądem cywilnym, gdyż mamy wtedy do czynienia z dozwolona przez prawo ingerencją w sferę dóbr osobistych.

Tok wywodów prowadzi do konkluzji, że ostatecznie o zakresie respektowania jawności rozprawy głównej powinien decydować sąd. Jest wyposażony w atrybut bezstronności i niezależności, a zatem jest najlepiej predestynowany do rozstrzygnięcia kolizji zbiegających się wartości, przemawiających za jawną rozprawą albo za wyłączeniem jawności ${ }^{21}$. Naturalnym porządkiem rzeczy prokurator tych przymiotów nie posiada, jako strona szczególna postępowania sądowego, występująca co prawda w obronie interesu społecznego, ale też w istotnym stopniu zainteresowana rozstrzygnięciem co do przedmiotu procesu. Niezrozumiałe jest formułowanie przez prokuratora sprzeciwu, który jest wiążący dla sądu jako organu prowadzącego postępowanie jurysdykcyjne i pełniącego kierowniczą rolę. Ustanowiono w ten sposób szczególny rodzaj nadzoru nad działalnością sądu, który też został istotnie ograniczony w możliwości podjęcia stosownej decyzji ${ }^{22}$. Wszak to sąd stoi na straży realizacji celów postępowania karnego, a to oznacza, że warunkiem dochowania konsekwencji w tym zakresie jest pozostawienie w rękach sądu wpływu na realizację funkcji zasady jawności.

Ważnym elementem sprawiedliwej procedury sądowej jest zaufanie, jakie wobec uczestników postępowania ta procedura powinna wzbudzaćc ${ }^{23}$. W tym kontekście pojawiają się więc wątpliwości o charakterze konstytucyjnym. Regulacja art. $360 \S 2$ k.p.k. rodzi bowiem zastrzeżenia w aspekcie konstytucyjnego prawa do sprawiedliwego rozstrzygnięcia sprawy przez sąd (art. 45 ust. 1 Konstytucji). Jak podkreśla się w doktrynie, sprawiedliwość proceduralna odnosi się do celu postępowania, gdyż zgodnie z art. 45 ust. 1 Konstytucji każdy ma prawo do orzeczenia w sprawie z zachowaniem podstawowych gwarancji

\footnotetext{
${ }^{21}$ W. Jasiński, w: J. Skorupka (red.), Kodeks..., s. 888.

22 M. Błaszyk, H. Paluszkiewicz, op. cit., s. 299 i 300.

${ }^{23}$ P. Wiliński, w: idem, (red.), op. cit., s. 304.
} 
umożliwiających osiagnięcie tego zamierzenia ${ }^{24}$. Rozstrzygnięcie w przedmiocie jawności rozprawy, z uwagi na swe znaczenie dla ochrony praw i interesów uczestników procesowych, powinno zapadać przy zachowaniu wymogu bezstronności i niezależności, czyli powinno być podejmowane przez sąd.

Drugi kierunek zmian nowelizacyjnych objętych ustawa z 10 czerwca 2016 r. dotyczył zagadnienia rejestracji audiowizualnej przebiegu rozprawy głównej (art. 357 k.p.k.). Przed wejściem w życie tej ustawy sąd udzielał w tej mierze zezwolenia na dokonywanie utrwaleń obrazu i dźwięku, gdy łącznie były spełnione trzy warunki: 1) przemawiał za tym uzasadniony interes społeczny, 2) dokonywanie tych czynności nie utrudniało prowadzenia rozprawy, 3) nie sprzeciwiał się temu ważny interes uczestnika postępowania. Niekoniecznie można było wtedy twierdzić o ustanowieniu tym sposobem regulacji wyjątkowej, niemniej decydentem w tym zakresie był sąd dokonujący analizy ustawowych warunków.

Treść art. 357 § 1 k.p.k. niedwuznacznie sugeruje, że de lege lata rejestracja audiowizualna staje się regułą w tym sensie, że na sądzie ciąży obowiązek dopuszczenia przedstawicieli mediów do utrwalania przebiegu rozprawy za pomoca specjalnej aparatury, gdy tylko wystapią oni do sądu o wydanie zezwolenia w tej materii. Na tle takiego unormowania bez cienia przesady można stwierdzić, że dziennikarze stają się gwarantem rejestracji audiowizualnej, ponieważ wyłącznie od nich zależy, które sprawy karne będą podlegać tej szczególnej formie sprawozdawczości sądowej, przy czym złożenie do sądu wniosku o zezwolenie na rejestrację wiąże sąd w tym sensie, że powinien dziennikarzy wówczas dopuścić (,sąd zezwala”).

Taki sposób skonstruowania tego uregulowania sprawia, że sąd nie dokonuje oceny wniosku złożonego przez przedstawicieli prasy ${ }^{25}$. Jedynym ograniczeniem, a tym samym jedynym warunkiem dopuszczalności owej rejestracji jest wzgląd na warunki techniczno-organizacyjne. W tę właśnie stronę zmierza treść art. 357 § 2 k.p.k., w którym przewiduje się, że sąd może określić warunki udziału w rozprawie przedstawicieli środków społecznego przekazu. Kontekst sytuacyjny i znaczeniowy normy wynikajacej z tego przepisu wskazuje, że chodzi tutaj o warunki związane z zapobieżeniem utrudnianiu przez dziennikarzy prowadzenia postępowania. Innymi słowy, chodzi o stworzenie odpowiednich warunków, które zagwarantuja, że nie dojdzie do zakłócania przebiegu rozprawy. W literaturze wskazuje się w tym kontekście np. na rozmieszczenie aparatury, liczbę kamer i mikrofonów czy też na sposób utrwalania rozprawy ${ }^{26}$. Jeżeli w ogóle obecność wspomnianych przedstawicieli miałaby utrudniać przebieg rozprawy z przyczyn techniczno-organizacyjnych, sąd sięga po rozwiązanie skrajne polegajace na ograniczeniu ich liczby w sali rozpraw i wskazaniu uprawnionych do dokonywania omawianej rejestracji w wyniku zastosowania kryterium losowania albo według kolejności zgłoszeń ${ }^{27}$ (art. 357

${ }^{24}$ P. Wiliński, Proces..., s. 98-106 i 119-120.

25 M. Błaszyk, H. Paluszkiewicz, op. cit., s. 303.

${ }^{26}$ W. Jasiński, w: J. Skorupka (red.), Kodeks..., s. 882.

${ }_{27} \mathrm{~W}$ doktrynie trafnie wskazuje się, że oba kryteria są rozłączne, a wybór jednego lub drugiego należy do sądu, zob. ibidem. 
$\S 3$ k.p.k.). Z kolei fakt zakłócania przez dziennikarzy przebiegu rozprawy musi implikować wydanie przez sąd zarządzenia o opuszczeniu przez nich sali rozpraw (art. $357 \S 4$ k.p.k.).

Nietrudno zauważyć, że z treści art. 357 k.p.k. zniknęła kategoria uzasadnionego interesu społecznego. Warto $\mathrm{w}$ tym miejscu podkreślić, że generalną zmianę treści tego przepisu ustawodawca motywował koniecznościa wzmocnienia transparentności procesu karnego przez zapewnienie kontroli społecznej nad prawidłowością przebiegu postępowania, zwłaszcza w realiach społeczeństwa informacyjnego, a zatem ex definitione przemawia za tym uzasadniony interes społeczny ${ }^{28}$. Nie sposób w płaszczyźnie ogólnej kontestować słuszności tych założeń, w szczególności gdy uwypuklona zostanie konieczność realizacji funkcji zasady jawności: kontrolnej, informacyjnej i gwarancyjnej. Problem jednak w tym, że pewne obawy może wzbudzać przesunięcie w stronę przedstawicieli prasy punktu ciężkości w zakresie doboru spraw będących przedmiotem rejestracji audiowizualnej. Można bowiem żywić wątpliwości, czy nie doszło w ten sposób do prawnego usankcjonowania zjawiska nieuzasadnionej społecznej ciekawości, pospolitego zainteresowania, „taniej sensacji” itd. Kategoria uzasadnionego interesu społecznego na gruncie poprzedniego stanu prawnego z pewnościa zabezpieczała przed wystapieniem tych negatywnych w swej istocie zjawisk kulturowych. Nie da się ukryć, że należy respektować interes społeczeństwa, ale w warunkach uwzględniających racjonalne zapotrzebowanie na informację. W przeciwnym razie interes zbiorowości może oznaczać prawne uznanie ciekawości społecznej opartej nawet na plotkach ${ }^{29}$. Zasadne są też obawy, że w sprawach budzących duże zainteresowanie opinii publicznej może dojść do eskalacji emocji ${ }^{30}$, co nie służy właściwemu utrwalaniu wizerunku wymiaru sprawiedliwości, czy wykraczając szerzej - kształtowaniu prawidłowych relacji społecznych.

Nie wydaje się, aby „uzasadniony interes społeczny” stanowił ustawowa podstawę mocno zawężającą możliwość rejestracji audiowizualnej. Kreuje bowiem potrzebę wydania zezwolenia przez sąd w każdym przypadku, w którym decyzja negatywna w tym względzie byłaby społecznie szkodliwa, nie mówiąc o tym, że da się wskazać konkretne wskaźniki podlegające analizie i zarazem przemawiające za rejestracją audiowizualna ${ }^{31}$. Z drugiej strony można kontrargumentować, że w istocie rozwój społeczeństwa informacyjnego niejako wymusza poszerzenie zakresu jawności zewnętrznej rozprawy przez poszerzenie dopuszczalnego zakresu wspomnianej rejestracji. W tym aspekcie być może należy zachować optymizm, przypominając, że z zainteresowaniem dziennika-

${ }^{28}$ Tę argumentację przytacza A. Ważny, w: A. Sakowicz (red.), op. cit., s. 844.

${ }^{29}$ A. Scalisi, Il diritto alla riservatezza, Milano 2002, s. 74.

${ }^{30}$ M. Błaszyk, H. Paluszkiewicz, op. cit., s. 303.

${ }^{31}$ Zob. szerzej R. Koper, Jawność rozprawy..., s. 348-351 i podana tam literatura. Por. także A. Gerecka-Żołyńska, P. Górecki, Rola środków społecznego przekazu na tle zasady domniemania niewinności, w: E. Dynia, C.P. Kłak (red.), Europejskie standardy ochrony praw człowieka a ustawodawstwo polskie, Rzeszów 2005, s. 415; M. Kuźma, Udziat mediów w procesie karnym, w: J. Skorupka (red.), Jawność..., s. 397-398. 
rzy na ogół spotykają się tylko niektóre sprawy karne ${ }^{32}$. Ten optymizm może być wszak osłabiony, gdy zwróci się uwagę na fakt, że współczesne dziennikarstwo wyraźnie zmierza w stronę „newsowości” (sensacyjności).

Jest rzeczą oczywista, że rejestracja audiowizualna jest możliwa jedynie wtedy, gdy nie doszło do wyłączenia jawności rozprawy. Można więc wstępnie zaryzykować stwierdzenie, że interes uczestnika postępowania (oskarżonego, pokrzywdzonego, świadka) podlega ochronie o tyle, o ile sąd zdecyduje się prowadzić rozprawę niejawnie. Formalnie rzecz biorac, de lege lata nie musi być już brany pod uwage podczas dopuszczania przedstawicieli środków społecznego przekazu w trybie art. 357 k.p.k.

Warto zauważyć, że ustawodawca słusznie dostrzega potrzebę uwzględnienia interesu świadka. W art. 357 § 5 k.p.k. przyznano przewodniczacemu składu sądzącego kompetencję w zakresie zarządzenia opuszczenia sali rozpraw przez przedstawicieli prasy na czas przesłuchania świadka, gdy zachodzi wyjątkowy przypadek, w którym należy się obawiać, że ich obecność mogłaby oddziaływać krępująco na zeznania świadka. Taką możliwość dostrzegała doktryna pod rządem poprzednich przepisów, gdy akcentowano konieczność zapewnienia realizacji zasady prawdy i reguły swobody wypowiedzi uczestników procesu, aby zagwarantować nieskrępowane składanie oświadczenia dowodowego w warunkach wolnych od barier psychologicznych związanych ze świadomością jego rejestrowania ${ }^{33}$. Nawiasem mówiac, istnienie takiej możliwości wywodzono z kategorii językowej „dokonywanie tych czynności nie będzie utrudniać postępowania”. Podkreślano jednakowoż, że omawiane swoiste prawo przysługuje także oskarżonemu, gdy deklaruje on chęć złożenia wyjaśnień, ponieważ trudno byłoby znaleźć kontrargumenty zmierzajace do wprowadzania jakiejś dyferencjacji w tym zakresie ${ }^{34}$. Skoro zatem dotychczas - w warstwie pozanormatywnej - jednolicie przyjmowano, że także oskarżony w wyjątkowych sytuacjach może skorzystać z takiego dobrodziejstwa, to fakt wyraźnego pominięcia oskarżonego w regulacji art. 357 $\S 5$ k.p.k. świadczy zapewne o braku de lege lata takiej możliwości. Biorąc pod uwagę, że sąd ma obowiązek dążyć do wszechstronnego i pełnego wyjaśnienia okoliczności sprawy, a w tym celu musi zadbać o optymalne warunki do składania wiarygodnych oświadczeń dowodowych uczestników procesu, takie rozwiąanie nie zasługuje na aprobatę.

Określone zastrzeżenia pojawiają się nadto, gdy pominiemy aspekt gwarancji procesowych, a skoncentrujemy uwagę na zagadnieniu ochrony dóbr osobistych uczestników postępowania. Z jednej strony można bronić tej nowej regulacji, wskazując, że zezwolenie na dokonywanie utrwaleń przebiegu rozprawy nie jest równoznaczne ze zgodą na publikację zarejestrowanych w ten sposób treści. Kwestia ewentualnej publikacji stanowi bowiem domenę zakazu prasowej publikacji danych osobowych i wizerunku uczestników procesu kar-

32 A. Gerecka-Żołyńska, P. Górecki, op. cit., s. 415.

${ }^{33}$ R. Koper, Jawność rozprawy..., s. 356-357 i cytowana tam literatura.

${ }^{34}$ Doktryna powszechnie akcentuje taką możliwość, zob. ibidem, s. 357-359 wraz z powołaną tam literatura. Z nowszych opracowań zob. W. Jasiński, w: J. Skorupka (red.), Kodeks..., s. 883. 
nego (art. 13 ust. 2-4 Prawa prasowego). Co prawda nie jest jednoznaczne, czy ów zakaz pozostaje w stosunku niezależności wobec zezwolenia wydawanego w trybie art. 357 k.p.k., ale trafny jest dominujacy w doktrynie pogląd o posiadaniu przez oba przepisy właśnie innych przedmiotów regulacji: art. 357 k.p.k. dotyczy tylko samej rejestracji, art. 13 ust. 2 Prawa prasowego odnosi się zaś do publikacji już utrwalonych treści ${ }^{35}$. Z drugiej strony zachodzi tutaj niebezpieczeństwo poświęcenia dóbr osobistych, a zwłaszcza prywatności, co może się wydawać niezrozumiałe w kontekście współczesnej rangi i znaczenia potrzeby poszanowania sfery osobistej człowieka. Dziennikarze nie moga rozpowszechniać (a zatem publikować) uzyskanych informacji, ale moga je rozgłaszać. Zachodzi nadto obawa opublikowania ich w prasie, wbrew wskazanemu zakazowi, zwłaszcza gdy będą to informacje, dzięki którym wzrośnie sprzedaż danego dziennika lub czasopisma lub generalnie wzrośnie stopień zainteresowania daną publikacją w określonych kręgach społecznych. Formułowanie takich obaw nie jest na wyrost - doświadczenia polskiej prasy lat ubiegłych stanowią w tym aspekcie potwierdzenie zasadności przejawianych wątpliwości.

Wyeksponowane negatywy nowego unormowania zawartego w art. $357 \mathrm{k} . p . k$. bardziej jednak sa konsekwencją działalności prasowej. Nie są bowiem wprost bezpośrednim skutkiem regulacji ustawowej. Gdyby dziennikarze sumiennie i wnikliwie przestrzegali obowiązujących przepisów prawnych, w tym także gdyby właściwie działali na rzecz interesu społecznego, prawdopodobnie można by wtedy zaakceptować tę nową regulację. Jak jednak sprawić, aby prasowa realizacja wymogów sprawozdawczości sądowej była prawidłowa - to już temat na osobną dyskusję, która zresztą do tej pory nie wykreowała żadnego skutecznego antidotum. Wydaje się, że aby chronić ważny (a nie: każdy) interes uczestników postępowania, dobrze by było, gdyby w treści art. 357 k.p.k. znalazła się wzmianka o respektowaniu takiego interesu indywidualnego.

Omówiona ustawa nowelizacyjna niewątpliwie wprowadziła zmiany w zakresie modelu jawności rozprawy głównej. Poszerzono zakres dostępności procesu karnego dla społeczeństwa. Idea większej otwartości postępowania sądowego w wymiarze zewnętrznym per se zasługuje na aprobatę. Szkoda, że potrzeba ochrony praw jednostki zeszła tutaj na drugi plan. Przypomnijmy, że zadośćuczynienie tej potrzebie stanowi czynnik rozwoju społeczeństwa ${ }^{36}$, w tym także czynnik sprzyjający integracji społecznej. Należałoby więc postulować, aby zmiany dotyczące jawności rozprawy głównej uwzględniały tę konieczność, istotna dla człowieka, zwłaszcza z punktu widzenia jego relacji z państwem.

dr hab. Radostaw Koper

Profesor Uniwersytetu Ślaskiego w Katowicach

radoslaw.koper@us.edu.pl

${ }^{35}$ R. Koper, Jawność rozprawy..., s. 342-345 i wskazana tam literatura.

${ }^{36}$ M. O’Flaherty, Ochrona praw człowieka $w$ dzisiejszej Europie, „Ruch Prawniczy, Ekonomiczny i Socjologiczny" 79, 2017, z. 1, s. 52-54. 


\section{OPENNESS OF THE MAIN HEARING IN A CRIMINAL TRIAL IN THE LIGHT OF THE AMENDMENTS TO THE CODE OF CRIMINAL PROCEDURE OF 2016}

\section{Sum mary}

The principle of openness, or transparency, being one of the guiding principles in criminal proceedings, is realised mainly during the first instance hearing. The amendment to the Code of Criminal Procedure of 10 June 2016 introduced two model changes in this respect. The article is devoted to the discussion of these changes. The first one concerns the decision to hear a case in camera. The prosecutor has been granted the right to object to the exclusion of a public hearing, which is binding on the court. This regulation raises constitutional concerns because it undermines the constitutional right to a fair trial. A disclosure should be decided on by an impartial and independent court, acting as an independent state body best placed to resolve conflicting values. The second fundamental change is the establishment of an audiovisual registration of the course of the hearing by representatives of the mass media. The court must allow them to hear the trial whenever they so request. In this respect, the removal of the condition of respect for the important interest of the party involved in the criminal proceedings was analysed and assessed negatively. The extension of the transparency of the main hearing, however, was generally given a positive assessment. 
